\title{
The Role of Perceived Social Support and Coping Styles in Predicting Adolescents' Positivity
}

\author{
Gülşen Büyükşahin Çevik*, Mehmet Ali Yıldız \\ Faculty of Education, Guidance and Psychological Counseling, Adryaman University, Turkey
}

Copyright $(\mathrm{C} 2017$ by authors, all rights reserved. Authors agree that this article remains permanently open access under the terms of the Creative Commons Attribution License 4.0 International License

\begin{abstract}
The current research aims to examine the perceived social support and coping styles predicting positivity. Research participants included 268 adolescents, attending high school, with 147 females (54.9\%) and 121 males $(45.1 \%)$. Adolescents participating in the research were 14 to 18 years old and their average age was 16.12 with $\mathrm{SD}=1.01$. Research data were analyzed through descriptive statistics, Pearson correlation coefficient, and multiple linear regression analysis. Research findings indicated that perceived social support and seeking for assistance among coping styles significantly predicted positivity and explained the $29 \%$ of variance in positivity. However, problem solving, cognitive avoidance, and behavioral avoidance among coping styles had no significant predictive effects on adolescents' positivity. In addition, it was found that variables of grade, gender, and age did not predict adolescents' positivity. Researchers discussed and interpreted findings in the light of relevant literature and put forward recommendations for relevant researchers. Based on the findings of the current research, social support may be important in terms of interventions for adolescent's development and mental health and that social support significantly predicts positivity. For adolescents, receiving support by parents, teachers, and peers in problematic academic or social relationships may positively is associated with their positivity as it can help them have positive considerations of their lives and be optimistic about future and solving their problems. Perceived social support and seeking assistance among coping styles may have significant roles in predicting adolescents' positivity. Adolescents may need to seek assistance to effectively cope with their problems and the perceived social support in the social environment upon receiving assistance increase their positivity as well. Also, seeking assistance, for adolescents, may positively affect positivity as it may mean that they are optimistic about solving their problems.
\end{abstract}

Keywords Perceived Social Support, Coping Styles, Positivity, Adolescents

\section{Introduction}

Positive psychology became a more discussed and researched field in psychology following 2000s [13, 16, 17, $59,64,65]$. Positive psychology is defined as a field that helps individuals to discover their positive and negative traits and to use their own potentials in the best manner [63, 72]. Also, Seligman and Csikszentmihalyi [77] stated that the field of positive psychology involved psychological well-being, contentment, satisfaction with past life experiences, hope for future, optimism, and happiness associated with current experiences, as well as individuals' subjective judgments. In general, positive psychology focuses on overcoming hardships in life as well as facilitating strengthening individuals' positive traits [77]. One of the important concepts developed in the field of positive psychology is positivity. Diener, Scollon, Oishi, Dzokoto, and Suh [24] defined positivity as individual's tendency to use generally better aspects of his/her life. On the other hand, Caprara et al. [13] stated that positivity consisted of a combination of self-esteem, satisfaction with life, and optimism. Self-esteem involves individuals' esteem towards themselves and their level of self-acceptance [42] and satisfaction with life is about all considerations associated with their lives [23]. On the other hand, optimism involves individuals' positive emotions about future $[1,8,78]$. A review of recent studies in the relevant literature indicates an increase in research on satisfaction with life and subjective well-being as concepts of positive psychology [19, 34, 36, 57, 60, 61, 69, 79]. However, recent studies on positivity have been limited in numbers. Castellani, Perinelli, Gerbino, and Caprara [11], among recent studies, found a negative relationship between positivity (self-esteem, satisfaction with life, optimism) and anxious and avoiding interpersonal styles. Yıldız [79], on the other hand, identified significant relationships between positivity and loneliness and emotion regulation. Caprara, Eisenberg, and Alessandri [10] found that positivity and positive affect mutually predicted each other. Thus, it was reported that research conducted on positivity as a new concept within the field of positive psychology was limited 
and positivity included concepts such as self-esteem, life satisfaction, and optimism [10]. The concept of positivity appeared as positive thinking $[14,16]$, positive orientation $[2,15]$, and positivity $[12]$ in the first studies in relevant literature.

Another variable that be associated with positivity is perceived social support. Social support has been described as the social and psychological assistance provided by others in an individual's environment [35].According to Robertson [73], however, social support included knowledge, skills experience, and assistance for the individual to see their own abilities, offered by others in order to help solve a problem. Also, perceived social support is the type of support provided to appreciate and praise the individual's achievements and to assist them in the organization of interpersonal relationships. Hence, adolescents with positive perceptions and feelings of their own lives and higher levels of life satisfaction were reported to also have positive inter-personal relationships [36]. Huebner, Antaramian, Hills, Lewis, and Saha [44] found that peer acceptance of adolescents and receiving social support led to less stressful life incidents and more life satisfaction in adolescents. Natvig, Albrektsen, and Qvarnstrøm [66] found that social support provided by teachers and peers was related to happiness. Thus, it was reported that schools functioned importantly in relation to socialization and social support and that the purpose of schooling and education was to enable increased happiness, life satisfaction, and positive emotions in children [67]. A review of studies conducted indicated that students receiving support by parents, school, and teachers had improved academic achievement and social relationships $[40,74]$. Social support predicted subjective well-being or life satisfaction $[38,75,82]$. Hence, it may be said that social support positively affects life satisfaction and subjective well-being. It was also found that perceived social support significantly predicted psychological well-being [91] and had a significant relationship with coping [33, 52, 92]. Some studies showed that perceived social support significantly predicted individual's coping and adjustment [41, 53]. Consequently, upon a review of the research, perceived social support may be considered to contribute positively in adolescents' development and help them to adjust, to have positive considerations of their own lives, to increase life satisfaction, and to effectively cope. Thus, it may be said that perceived social support may positively is associated with positivity.

Coping, on the other hand, is among the variables that are associated with positivity. Lazarus and Folkman [56] described coping as cognitive and behavioral efforts that an individual put forward to manage internal and external demands consuming and over-challenging his/her resources. However, Bandura [4] defined coping as a product of interactive process between personality and situation. Theoretical studies on coping with stress fall into two basic groups as biological and psychosocial. In the process of adjusting to live, a living thing must, first of all, tend to survive. It was reported that living things needed to protect three balance areas such as biological, psychological, and social areas, to survive. Experiences directly impacting life (war, accident, diseases, etc.) as well as psycho-social experiences that may contain threats against life (failure, loss, daily hardships, etc.) affect this balance, in relation to individual's survival. Hence, the purpose of adjustment processes in stress or threat situations was reported to be enabling the individual to regain the balance. Reactions of coping put forward in these processes were reported to be physiological, emotional, behavioral, and cognitive $[5,55$, 84].

On the other hand, factors impacting the quality of coping include being able to think positively, having problem solving skills, perception of control, self-efficacy believes, and perceptions of self, depressive tendencies, social relationships, demographic characteristics, gender, optimism, and similar personal characteristics [22, 56]. Thus, in relation to both positivity and coping, social support, positive orientation, and optimism may be considered significant and related components. A similar study found in the relevant literature indicated that adolescents with less stressful lives more effectively use subjective well-being, self-control, and problem-focused coping skills [48]. Dursun [28] found that being optimistic and happy increased positive emotions and that there was a positive relationship between social support sought after or received upon a stressful incident or in a stressful situation by individuals and their positive emotions. Significant relationships between positive affect and coping were found [62]. Teoman [86] found that positive psychology applications were effective on seeking social support as the sub-dimension of coping, optimism and functional coping style. Topal [90] found a negative relationship between problem-focused coping style and negative emotions; a positive relationship between this and positive emotions; and a negative relationship between seeking social support and negative emotions. Tyler and Cushway [89] found that avoidance among coping styles against stress negatively affected subjective well-being. On the other hand, Smith, Seltzer, Tager-Flusberg, Greenberg, and Carter [80] determined a positive relationship between less use of emotion-focused coping styles and frequent use of problem-focused coping style and subjective well-being. Deniz [26] found a positive relationship between coping styles (problem-focused coping, seeking social support) and life satisfaction. Duman [27] revealed a negative relationship between subjective well-being and submissive approach among coping styles with stress. Considering the studies mentioned above, it may be said that coping is associated with optimism, subjective well-being, social support, and positive emotions and, also, that coping may be an important variable due to its predictive effect on life satisfaction.

The current research examined the role of social support 
and coping styles predicting adolescents' positivity. Adolescence starting with puberty and continuing until adulthood is defined as a transition period between childhood and adulthood [96]. In this transition period, the use of effective and functional coping styles by adolescents against problems and their perceived social support are thought to be associated with their positivity. In addition, considering positivity with dimensions such as self-esteem, life satisfaction, and optimism, understanding the variables impacting positivity concept in adolescents' educational, social, and personal development may be important. Many studies on adolescence indicated that subjective well-being or life satisfaction would positively contribute in adolescent's life $[10,31,32,71,79]$. Thus, studying the variables predicting positivity in adolescence may be considered significant. Research on positivity began with the study conducted by Caprara, Steca, Gerbino, Paciello, and Vecchio [16]. A review of studies on positivity in the relevant literature indicates that positivity is just a new concept and the number of studies on positivity is limited. Also, a research examining the effect of social support and coping styles used on predicting adolescents' positivity has not been found among the conducted studies. Thus, studies on positivity and variables predicting positivity may greatly contribute in adolescents' development in personal, emotional, social spheres. Hence, research on the relationship between perceived social support, coping styles, and positivity in adolescents is considered important and necessary in terms of contributing in activities conducted to improve adolescents' positivity levels by practitioners (psychiatrists, psychologists, psychological counselor) offering services in the spheres of mental health, prevention, and intervention.

\section{The Purpose of the Study}

The current research aims to find out the extent to which adolescents' perceived social support, coping strategies predict their positivity. The following research questions were put forward based on this purpose:

- To what extent does adolescents perceived social support predict their positivity?

- To what extent does adolescents coping strategies predict their positivity?

\section{Method}

\subsection{Research Design}

Researchers used a relational design in the current research. According to Heppner, Wampold, and Kivlighan [43], relational designs are used in studying relationships between two or more variables. In the current research, the predictive power of perceived social support (predicting variable) and coping styles (predicting variables) on positivity (predicted variable) was examined through regression analysis.

\subsection{Participants}

The participants included 268 adolescents attending high schools in 2015-2016 academic years in the city of Adiyaman, Southeastern Region, Turkey. Among participants, 147 were females $(54.9 \%)$ and 121 were males (45.1\%). Ages of participant adolescents ranged from 14 to 18 with an average age of $16.12, \mathrm{SD}=1.01$. Convenience sampling method was used to determine the research participants.

\subsection{Instruments}

The Reviewed Form of Multidimensional Scale of Perceived Social Support: The original scale, used to define the level of individual's perceived social support, was developed by Zimet, Dahlem, Zimet, and Farley [100]. Eker, Arkar, and Yaldı [30] conducted the validity and reliability studies for the reviewed form of the scale. The scale was a 7-point Likert-type scale with "1=I Strongly Disagree - 7=I Strongly Agree". The scale consists of 12 items with three sub-dimensions within four items for defining the support by family, friend, and special person. Dimensions on the scale include four items each. Scores can be obtained separately on each dimension as well as a total scale score is available. Higher scores on the scale indicate an increase in the perceived social support. In the current study, the internal consistency coefficient for the whole scale was found to be .79 .

The Positivity Scale (PS): Positivity Scale, developed by Caprara et al. [12] is a scale defining individuals' positivity levels. The adaptation studies for PS into Turkish language were conducted by Duy and Yildiz [29]. PS is a single-dimension scale with 8 items. PS is a 7-point Likert-type scale with " $1=\mathrm{I}$ Strongly Disagree $-7=\mathrm{I}$ Strongly Agree". A high total score on the scale indicates increased levels of positivity in individuals. The exploratory factor analysis conducted by Duy and Yıldiz [29] showed that PS explained $44.75 \%$ of the total variance in high-school adolescents and $45.04 \%$ in young adults in university. Factor loads in adolescents were found between .33 and .77 and between .35 and .79 in young adults. Also, the scale-invariance for PS between adolescents and young adults was provided. Significant-level relationships were found between positivity and optimism sub-dimension (adolescents, $\mathrm{r}=.43$, young adults, $\quad r=.63$ ), pessimism sub-dimension (adolescents, $\mathrm{r}=-.36$, young adults, $\mathrm{r}=-.57$ ), optimism total score (adolescents, $\mathrm{r}=.48$, young adults, $\mathrm{r}=.68$ ), positive affect (adolescents, $\mathrm{r}=.55$, young adults, $\mathrm{r}=.55$ ), negative affect (adolescents, $r=-.47$, young adults, $r=-.40$ ), life satisfaction (adolescents, $\mathrm{r}=.60$, young adults, $\mathrm{r}=.73$ ), and self-esteem (adolescents, $\mathrm{r}=.62$, young adults, $\mathrm{r}=.54$ ) in the 
criterion validity analyses for PS Cronbach's alpha internal consistency coefficient for the scale was found to be $\alpha=.81$ for both groups. The scale internal consistency coefficient in the current study was found as .79.

Coping Scale for Children and Youth (CSCY): The adaptation studies into Turkish language for the scale, developed by Brodzinsky et al. [7] to define coping styles of children and youth, were conducted by Yildiz [20]. CSCY has four sub-dimensions such as assistance seeking, problem solving, cognitive avoidance, and behavioral avoidance. The scale was a 4-point Likert-type scale with " $1=$ Never $-4=$ Always". The dimension of seeking assistance includes four items; problem solving, seven items; cognitive avoidance, ten items; and behavioral avoidance dimension includes three items. The scale does not yield a total score. Based on the scores that an individual obtains on each dimension, his/her coping style is defined. The scale consists of 24 items and $\chi^{2}=506.02, \mathrm{df}=246, \chi^{2} / \mathrm{df}=2.06$, $p<.01, \mathrm{RMSEA}=.05, \mathrm{SRMR}=.06, \mathrm{GFI}=.90, \mathrm{AGFI}=.87$, $\mathrm{CFI}=.93$ were found in the confirmatory factor analysis conducted for construct validity. In addition, CSCY cross validation (metric invariance) was provided in male and female samples. The correlation values obtained for CSCY test-retest reliability ranged between .32 and .67. CSCY internal consistency coefficients were found to be .68 for assistance seeking, .70 for problem solving, .32 for behavioral avoidance, and .82 for cognitive avoidance. CSCY combined reliability values were calculated to be between .44 and .81 . In the current study, the internal consistency coefficient for seeking assistance was found to be $.51 ; .79$ for problem solving; .84 for cognitive avoidance; and .47 for behavioral avoidance.

Personal Information Form: The Personal Information Form was developed by the researchers to determine participants' grade levels, genders, ages, and levels of income.

\subsection{Procedure}

Researchers conducted the data collection for the current research upon obtaining required permissions. The researchers collected the data from volunteering students at schools upon obtaining required permission for collecting data at high schools from the Department of Education. Volunteering students participated in the research. First of all, the hypotheses within the regression analysis were tested for whether they were met in the current study. Research data analysis indicated that skewness and kurtosis values were between the accepted +1 and -1 . Mahalanobis critical value for five independent variables was 20.52 [70].Based on the values obtained in the current study, five people with outliers were excluded and a total of 268 participants (Mahalanobis value $=19.56$ ) were in the analyses. Research variables with no very high-level correlation values indicated that there were no multiple association problems among variables. In addition, VIF, Tolerance and Durbin-Watson values, reviewed to check whether there was a multiple linearity problem among variables, indicated that there was no multiple linearity problem. Also, Cook distance values were found to be below critical value 1 [85]. Above- mentioned values indicated that data were distributed normally and hypotheses of the regression analysis were met. In the analysis of research data, first of all, the predictive power of grade level, gender, and age on positivity was examined through multiple linear regression analysis. As the predictive effect of demographic variables on positivity was not on significant levels, those variables were not included in further analyses. Later, the predictive effect of perceived social support and coping styles on positivity was examined through multiple linear regression analysis. Researchers used descriptive statistics, Pearson correlation coefficient, and multiple linear regression analysis in the analysis of research data. Data analysis was conducted through IBM 22.0 software. The significance level for the current study was set as .05 .

\subsection{Findings}

Correlations between variables and descriptive statistics are presented in Table 1.

As can be seen in Table 1, there was a positive moderate level significant relationship between perceived social support and seeking assistance; a positive low-level significant relationship between perceived social support and problem solving; and a positive moderate -level significant relationship between perceived social support and positivity. No significant relationships took place between perceived social support and cognitive and behavioral avoidance. Also, a moderate -level positive significant relationship between positivity and seeking assistance and a low-level positive significant relationship between positivity and cognitive avoidance and a low-level positive significant relationship between positivity and behavioral avoidance were found. No significant relationship was found between positivity and cognitive and behavioral avoidance.

A review of multiple regression analysis results indicates that the model used to examine the predictive effect of demographic variables on positivity was not significant $\left.\left[\mathrm{F}_{(3,264)}=.55, p>.05\right)\right]$ and all demographic variables explained $1 \%$ of variance on positivity scores $(\mathrm{R}=.08$, $\left.\mathrm{R}^{2}=.01\right)$.

The predictive power of perceived social support and coping styles, as independent research variables, on positivity was examined through multiple standard regression analysis method. The results of regression analysis are presented in Table 2 . 
Table 1. Bivariate correlations and descriptive statistics of study variables

\begin{tabular}{|l|c|c|c|c|c|c|}
\hline \multicolumn{1}{|c|}{ Variables } & 1 & 2 & 3 & 4 & 5 & 6 \\
\hline 1. Perceived social support & --- & & & & & \\
\hline 2. Assistance seeking & $.39^{* *}$ & --- & & & & \\
\hline 3. Problem solving & $.25^{* *}$ & $.41^{* *}$ & --- & & & \\
\hline 4. Cognitive avoidance & .10 & -.12 & -.10 & --- & & \\
\hline 5. Behavioral avoidance & .07 & $-.13^{*}$ & -.11 & $.61^{* *}$ & --- & \\
\hline 6. Positivity & $.46^{* *}$ & $.41^{* *}$ & $.26^{* *}$ & .09 & .06 & -- \\
\hline Mean & 55.81 & 10.13 & 19.21 & 19.62 & 6.39 & 28.15 \\
\hline SD & 13.41 & 2.38 & 4.21 & 6.13 & 2.09 & 6.07 \\
\hline Skewness & -.34 & .10 & -.02 & .83 & .33 & -.50 \\
\hline Kurtosis & -.09 & -.32 & -.50 & .49 & -.55 & .12 \\
\hline
\end{tabular}

$* p<.05, * * p<.01$

Table 2. Predictive role of perceived social support and coping strategies on positivity

\begin{tabular}{|l|c|c|c|c|c|c|}
\hline Variables & $\mathrm{B}$ & $\beta$ & $\mathrm{t}$ & $\mathrm{R}$ & $\mathrm{R}^{2}$ & $\mathrm{~F}$ \\
\hline Perceived social support & .15 & .32 & $5.64^{* * *}$ & .54 & .29 & $21.50^{* * *}$ \\
\hline Assistance seeking & .68 & .27 & $4.41^{* * *}$ & & & \\
\cline { 1 - 4 } Problem solving & .11 & .08 & 1.37 & & & \\
\cline { 1 - 4 } Cognitive avoidance & .08 & .09 & 1.30 & & & \\
\cline { 1 - 4 } \cline { 1 - 4 } Behavioral avoidance & .08 & .03 & .44 & & & \\
\hline
\end{tabular}

${ }^{*} p<.05, * * p<.01, * * * p<.001$

Based on the results of multiple standard regression analysis, a moderate-level relationship $\left(\mathrm{R}=.54, \mathrm{R}^{2}=.29\right.$, $p<.05)$ was found between perceived social support and coping styles combined and positivity. Perceived social support and coping styles combined explain the $29 \%$ of variance in positivity. In addition, the model was seen to be on significant levels $\left[F_{(5,262)}=21.50, p<.001\right]$. Based on the standardized regression coefficient, relative significance order of predicting variables on positivity is as follows: perceived social support $(\beta=.32)$ and assistance seeking $(\beta=.27)$. A review of t-test results about the significance of regression coefficients indicates that perceived social support ( $\mathrm{t}=5.64, p<.001)$ and assistance seeking $(\mathrm{t}=4.41$, $p<.001)$ were significantly predictive on positivity. However, problem solving $(\mathrm{t}=1.37, p>.05)$, cognitive avoidance $(\mathrm{t}=1.30, p>.05)$, and behavioral avoidance $(\mathrm{t}=.44, p>.05)$ were not significantly effective on positivity.

\section{Discussion and Conclusion}

The current research examined the role of perceived social support and coping styles in predicting adolescents' positivity. Research results indicated a moderate -level significant relationship between perceived social support and positivity. In addition, it was found that perceived social support and coping styles combined predicted the positivity; based on the relative significance order on positivity, predicting variables included perceived social support and seeking assistance among coping styles. On the other hand, problem solving, cognitive avoidance, and behavioral avoidance among coping styles were found to have no significant-level predictive power on positivity.

Also, the social support perceived by the individual increases, the level of positivity increases. Namely, perceived social support is associated withindividuals' positivity. This may be based on the social network that adolescents are in through receiving social support because adolescents in a social network may have more positive considerations of their lives. Perceived social support may positively is associated with adolescents' development and social relationships, in emotional terms. Hence, studies supporting the findings of the current research discovered positively significant relationships between perceived social support and life satisfaction [93, 67] and psychological well-being [37]. Particularly considering that positivity includes optimism, life satisfaction, and self-esteem [13], it may be said that perceived social support leading to increased optimism about life and increased self-esteem levels in adolescents may positively is associated withtheir positivity as well. In a research that may support this interpretation, Kuzucu and Özdemir [54] found that parent participation perceived by adolescents reduced adolescents' depression levels and increased their life satisfaction and self-esteem. Family support was associated with psychological stress and emotional problems [25]. Turner [88] reported that peer support helped individuals feel efficient and successful, improve effective coping styles, and increase self-esteem. Karatzias, Power, and Swanson [51] found that perceived social support positively affected individuals' positive considerations of interpersonal relationships and school. In addition, individuals receiving social support better coped with stressful life events and increased life satisfaction [44]. Huurre, Kamulainen, and 
Aro [45] found the peer support perceived in adolescence to positively impact to increase adolescents' ability to control surroundings. Greenglass and Fiksenbaum [39] found that social support led to positive consideration of individuals' lives and effective confrontation of their problems. Also in other studies supporting the findings of current research, life satisfaction, social support, and self-esteem were reported to have positive relationships with optimism [6, 49]. Many studies conducted indicated to a significant relationship between subjective well-being and perceived social support [38, 82, 75, 83, 95]. Sayar [76] found significant relationships between teacher and peer support and psychological well-being and depression. Nur-Şahin [68] found a positive relationship between perceived social support and subjective well-being and the level of one's self-opening up. Based on the findings of the current research, social support may be important in terms of interventions for adolescent's development and mental health and that social support significantly predicts positivity. For adolescents, receiving support by parents, teachers, and peers in problematic academic or social relationships may positively is associated with their positivity as it can help them have positive considerations of their lives and be optimistic about future and solving their problems.

Another finding of the research indicated that seeking assistance among coping styles significantly predicted positivity. Namely, as scores obtained on the dimension of seeking assistance increased, adolescents' positivity significantly increased and seeking assistance significantly predicted positivity. Seeking assistance, for adolescents, when facing a problem in their lives, may be considered a healthy and functional coping style. Adolescents may probably be sustaining their well-being when they seek assistance in their social environment to maintain or increase their positivity against stressful events and situations. In addition, research findings may be supporting one another. In other words, perceived social support and seeking assistance among coping styles combined predict positivity. Both of these variables may be associated with each other as they are about individuals' social conditions. Thus, adolescents are expected to be willing to seek assistance prior to receiving social support and later to receive social support and to perceive it all along as well. In a study supporting the findings of current research, Çalık-Var, Varlıklar-Demirkazık, and Kolay-Çepni [18] found that being optimistic and seeking social support when coping with stress predicted the life satisfaction. In other studies supporting the findings of the current research, significant relationships between positive affect and coping [62] and a positive relationship between sub-dimensions (problem-oriented coping, seeking assistance) of coping and life satisfaction [26] were found. Jim, Richardson, Golden-Kreutz, and Andersen [47] determined that active coping predicted life satisfaction. Positive relationships were found between coping with stress, optimism, hopelessness, and subjective well-being [21, 50, 94]. Suldo and Huebner [81] found that as life satisfaction increased in adolescents, they coped with their problems better and experienced less emotional and behavioral problems. Gąsior, Biedrzycka, Chodkiewicz, Ziółkowski, Czarnecki, Juczyński, and Nowakowska-Domagała (2016) found positive significant relationships between coping with stress and life satisfaction. Antaramian, Kamble, and Huebner [3] revealed in a study conducted with adolescents that more females than males used seeking assistance among coping styles and problem solving as a coping style predicted life satisfaction. Li, Delvecchio, Lis, Nie, and Di Riso [58] found that negative coping was negatively and positive coping was positively significantly related with life satisfaction. Smith, Seltzer, Tager-Flusberg, Greenberg, and Carter [80] found that subjective well-being had a negative relationship with emotion-focused coping as a sub-dimension of coping and a positive significant relationship with problem-focused coping. Terzi and Cihangir Çankaya [87] concluded that secure attachment style and active planning among sub-dimensions of coping with stress significantly predicted seeking external assistance and taking refuge in religion and obsessive attachment, on the other hand, significantly predicted life satisfaction. Furthermore, sub-dimension of avoidance was found to have a negative relationship with subjective well-being when coping with stress [89]. Iş1k and Bedel [46] found a positive relationship between active coping and satisfaction with family relations, positive affect, and life satisfaction and a negative relationship between negative coping and satisfaction with family relations, positive affect, life satisfaction, and satisfaction with relationships. Also, it was found that significant predictors of subjective well-being were respectively active and negative coping and subjective well-being was not predicted by avoidance as a coping style. Consequently, perceived social support and seeking assistance among coping styles may have significant roles in predicting adolescents' positivity. Adolescents may need to seek assistance to effectively cope with their problems and the perceived social support in the social environment upon receiving assistance increase their positivity as well. Also, seeking assistance, for adolescents, may positively affect positivity as it may mean that they are optimistic about solving their problems.

Based on the findings in the current research, following may be recommended for psychiatrists, psychological counselor, and psychologists working with adolescents. Within the developmental preventive psychological counseling and guidance services, conducting psycho-educational activities about social support and coping, associated with improving positivity, may be recommended. As positivity is a new concept and studies on predictive powers are new, educational seminars and workshops on the role of predicting variables (social support, seeking assistance) for adolescents, parents, teachers, and administrators may be organized. Planning 
about improving social skills and peer relationships, in terms of searching for and developing resources about social support, may be conducted within individual psychological counseling interventions for developing positivity.

In future studies, finding out about other factors such as depression, hopelessness, self-esteem, traumatic experiences, anger, etc. that could predict positivity may be beneficial. In addition, experimental studies on perceived social support predicting positivity and the effect of coping may be conducted. The current research participants were adolescents; thus, variables predicting positivity with children, adults, and elders, covering various age groups, may be studied.

\section{Limitations}

The current research is limited to the characteristics measured by the Reviewed Form of Multidimensional Scale of Perceived Social Support, Positivity Scale, and Coping Scale for Children and Youth used. Totally 268 adolescents attending high schools in 2015-2016 academic years in the city of Adiyaman, Turkey, participated in the current research. To generalize the findings, the study must be conducted in different regions and cities as well.

\section{REFERENCES}

[1] Alessandri, G., Borgogni, L., Schaufeli, B. W., Caprara, G. V. \& Consiglio, C. (2015). From positive orientation to job performance: The role of work engagement and self-efficacy beliefs. Journal of Happiness Studies, 16, 767-788.

[2] Alessandri, G., Caprara, G. V., \& Tisak, J. (2012). The unique contribution of positive orientation to optimal functioning. European Psychologist, 17, 44-54.

[3] Antaramian, S., Kamble, S., \& Huebner, E. (2016). Life satisfaction and coping in Hindu adolescents in India. Journal of Happiness Studies, 17 (4), 1703-1717.

[4] Bandura, A. (1977). Social learning theory. Englewood Cliffs, NJ: Prentice Hall.

[5] Baum, A., Singer, J. E. \& Baum, C. (1981). Stress and the environment. Journal of Social Issues, 37(1), 4-33.

[6] Benyaminia, Y., Leventhal, H. \& Leventhal, E. A. (2004). Self-rated oral health as an independent predictor of self-rated general health, self-esteem and life satisfaction. Social Science and Medicine, 59, 1109-1116.

[7] Brodzinsky, D. M., Elias, M. J., Steiger, C., Simon, J., Gill, M., \& Hitt, J. C. (1992). Coping Scale for children and youth: Scale development and validation. Journal of Applied Developmental Psychology, 13, 195-214.

doi: 10.1016/0193-3973(92)90029-H
[8] Busseri, M. A., Choma, B. L., \& Sadava, S. W. (2009). As good as it gets or the best is yet to come? How optimists and pessimists view their past, present, and anticipated future life satisfaction. Personality and Individual Differences, 47, 352-356.

[9] Zimet, G. D., Dahlem, N. W., Zimet, S. G., \& Farley, G. K. (1988). The multidimensional scale of perceived social support. Journal of Personality Assessment, 52(1), 30-41.

[10] Caprara, G.V., Eisenberg, N., \& Alessandri, G. (2016). Positivity: the dispositional basis of happiness, Journal of Happiness Study, DOI 10.1007/s10902-016-9728-y.

[11] Castellani, V., Perinelli, E ., Gerbino, M., \& Caprara, G.V. (2016). Positive orientation and interpersonal styles, Personality and Individual Differences, 98, 229-234.

[12] Caprara, G. V., Alessandri, G., Eisenberg, N., Kupfer, A., Steca, P., Caprara, M. G. \& Abela, J. (2012). The positivity scale. Psychological Assessment, 24(3), 701-712.

[13] Caprara, G. V., Fagnani, C., Alessandri, G., Steca, P., Gigantesco, A., Sforza, L. L. C., \& Stazi, M. A. (2009).Human optimal functioning: The genetics of positive orientation towards self, life, and the future. Behavior Genetics, 39(3), $277-284$

[14] Caprara, G. V., \& Steca, P. (2005). Affective and social self-regulatory efficacy beliefs as determinants of positive thinking and happiness. European Psychologist, 10(4), 275-286.

[15] Caprara, G. V., Steca, P., Alessandri, G., Abela, J. R., \& McWhinnie, C. M. (2010). Positive orientation: Explorations on what is common to life satisfaction, self-esteem, and optimism. Epidemiologia e Psichiatria Sociale, 19(1), 63-71.

[16] Caprara, G. V., Steca, P., Gerbino, M., Paciello, M., \& Vecchio, G. M. (2006). Looking for adolescents' well-being: Self-efficacy beliefs as determinants of positive thinking and happiness. Epidemiologia e Psichiatria Sociale, 15(1), 30-43.

[17] Cohn, M. A., \& Fredrickson, B. L. (2010). In search of durable positive psychology interventions: Predictors and consequences of long-term positive behavior change. The Journal of Positive Psychology: Dedicated to Furthering Research and Promoting Good Practice, 5(5), 355-366.

[18] Çalık-Var, E., Varlıklar-Demirkazık, Ç. N., \& Kolay-Çepni, Ş. (2016). Coping stress as predictor of life satisfaction among older adults, Journal of Human Sciences, 13(3), 4048-4057.

[19] Çam, Z., \& Artar, M. (2014). Life satisfaction during adolescence: An examining context of school types. Journal of Social Sciences of Muş Alparslan University, 2(1), 23-46.

[20] Yıldız, M. A. (In Press). Çocuk ve ergenler için baş etme ölçeğinin Türkçe'ye uyarlanması: Geçerlik ve güvenirlik çalışmaları [Adaptation of the coping scale for children and youth to Turkish: Validity and reliability studies]. Çocuk ve Gençlik Ruh Sağlı̆̆ Dergisi.

[21] Daukantaite, D., \& Zukauskiene, R. (2012). Optimism and subjective well-being: Affectivity plays a secondary role in the relationship between optimism and global life satisfaction in the middle-aged women. Longitudinal and cross-cultural findings. Journal of Happiness Studies, 13, 1-16. 
[22] De Catanzaro, D. (1995). Reproductive status, family interactions, and suicidal ideation: Surveys of the general public and high-risk groups. Ethology and Sociobiology, 16, 385-394.

[23] Diener, E., Emmons, R. A., Larsen, R. J., \& Griffin, S. (1985). The satisfaction with life scale. Journal of Personality Assessment, 49, 71-75.

[24] Diener, E., Scollon, C. K. N., Oishi, S., Dzokoto, V., \& Suh, E. M. (2000). Positivity and the construction of life satisfaction judgments: Global happiness is not the sum of its part. Journal of Happiness Studies, 1, 159-176.

[25] Demaray, M. K., Malecki, C. K., Davidson, L. M., Hodgson K. K., \& Rebus, P. J. (2005). The relationship between social support and student adjustment: a longitudinal analysis. Psychology in the School, 42, 691-706.

[26] Deniz, M. E. (2006). The relationships among coping with stress, life satisfaction, decision making styles and decision self-esteem: an investigation on Turkish university students. Social Behavior and Personality: An International Journal, 34(9), 1161-1170.

[27] Duman, S. (2016). Analyzing the relationship between subjective well-being and self-esteem levels with the stress coping strategies university students, Unpublished Master Thesis, Beykent University Social Sciences Institute, İstanbul.

[28] Dursun, P. (2012). The role of meaning in life, optimism, hope, and coping styles in subjective well-being, Unpublished Doctoral Thesis. Middle East Technical University, Ankara.

[29] Duy, B., \& Y1ldiz, M. A. (2015). Investigation of the psychometric properties of the positivity scale (P Scale) for Turkish adolescents and young adults, APCCC 2015 Asia Pacific Counseling Conference, 18-19 June, 2015,Singapur. (https://www.counseling.org/docs/default-source/2015-singap ore-conference/op4-baki duy.pptx?sfvrsn=2)

[30] Eker, D., Arkar, H., \& Yaldız, H. (2001). Factorial structure, validity, and reliability of revised form of the multidimensional scale of perceived social support. Turkish Journal of Psychiatry, 12(1), 17-25.

[31] Eryllmaz, A. (2010).Developing a scale about subjective well-being increases strategies for adolescents. Turkish Psychological Counseling and Guidance Journal, 4(33), 81-88.

[32] Eryılmaz, A., \& Öğülmüş, S.( 2010). Subjective well-being and big five personality model at adolescence, Journal of Kirşehir Education Faculty, 11(3), 189-203.

[33] Frrat, N. (2015). An examination of social support level and stress coping strategies of students staying at home or in dormitory, Unpublished Master Thesis, Gaziosmanpaşa University Educational Sciences Institute, Tokat.

[34] Frisch, M. B. (2000). Improving mental and physical health care through quality of life therapy and assessment. In E. Diener \& D. R. Rahtz (Eds.) Advances in quality of life theory and research, 207-241. Great Britain: Kluwer Academic Publishers.

[35] Y1ldırım, İ. (2007). Depression, test anxiety and social support among Turkish students preparing for theuniversity entrance examination. Eurasian Journal of Educational Research, 29, 171-184.
[36] Gilman, R., \& Huebner, E. S. (2006). Characteristics of adolescents who report very high life satisfaction. Journal of Youth and Adolescence, 35(3), 311-319.

[37] Goldsmith, D. J. (2004). Communicating social support. New York. Cambridge University Press.

[38] González-Carrasco, M., Casas, F., Malo, S., Vinãs, F., \& Dinisman, T. (2016). Changes with age in subjective well-being through the adolescent years: differences by gender. Journal of Happiness Studies, 1-26.

[39] Greenglass, E. R., \& Fiksenb, L. (2009). Proactive coping, positive affect, and well-being testing for mediation using path analysis. European Psychologist, 14(1), 29-39.

[40] Gutman, L. M., \& Midgley, C.L. (2000). The role of protective factors in supporting the academic achievement of poor African American students during the middle school transition. Journal of Youth and Adolescence, 29(2), 223-248.

[41] Gülaçt1, F. (2010). The effect of perceived social support on subjective well-being. Procedia-Social and Behavioral Sciences, 2(2). 3844-3849.

[42] Harter, S. (1993). Causes and consequences of low self-esteem in children and adolescents. In R. F. Baumeister (Ed). Self-esteem: The puzzle of low self-regard (pp. 87-116). New York, NY: Plenum.

[43] Heppner, P. P., Wampold, B. E., \& Kivlighan, D. M., Jr. (2013). Psikolojik danışmada araștırma yöntemleri [Research design in counseling]. (D. M. Siyez, Trans.). Ankara, Turkey: Mentis Yayıncilik.

[44] Huebner, E. S., Antaramian, S., Hills, K., Lewis, A., \& Saha, R. (2010). Stability and predictive validity of the BMSLSS. Child Indicators Research, 4, 161-168.

[45] Huurre, T. M., Komulainen, E. J., \& Aro, H. M. (1999). Social support and self-esteem among adolescents with visual impairments. Journal of Visual Impairment, 93, 26-41.

[46] Işık, E. \& Bedel, A. (2015). Relationship of coping strategies to subjective well-being among adolescents, Selçuk Unıversity The Journal of Institute of Social Sciences, 34, 53-60.

[47] Jim, H. S., Richardson, S. A., Golden-Kreutz, D. M. \& Andersen, B. L. (2006). Strategies used in coping with a cancer diagnosis predict meaning in life for survivors. Health Psychology, 25(6), 753-761.

[48] Joronen, K. (2005). Adolescents' subjective well-being in their social context. Unpublished Master Thesis. University of Tampere Department of Nursing Science.

[49] Kapıkıran, Ş. (2013). Loneliness and life satisfaction in Turkish early adolescents: The mediating role of self-esteem and social support. Social Indicators Research, 111(2), 617-632.

[50] Karademas, E. C. (2007). Positive and negative aspects of well-being: Common and specific predictors. Personality and Individual Differences, 43, 277-287.

[51] Karatzias, A., Power, K. G., \& Swanson, V. (2001). Quality of school life. Development and preliminary standardization of an instrument based on performance indicators in Scottish secondary schools. School Effectiveness and School Improvement, 12(3), 265-284. 
[52] Koyuncu, Ö. (2015). Psycho - social determinants of resilience with people experienced parental loss: Condition of the loss, view of self, world and future, perceived social support and coping mechanisms, Unpublished Master Thesis, Hacettepe University Social Sciences Institute, Ankara.

[53] Kozakl1, H. (2006). The Relation between social support and loneliness as perceived by the undergraduates who accommodate at the dormitories and their families, Unpublished Master Thesis, Mersin University Social Sciences Institute, Mersin.

[54] Kuzucu, Y., \& Özdemir, Y. (2013). Predicting adolescent mental health in terms of mother and father involvement, Education and Science, 38(168), 96-112.

[55] Lazarus, R. S. (1991). Psychological stress in the workplace. Handbook on job stress, Journal of Social Behavior personality, 6(7), 1-9.

[56] Lazarus, R. S., \& Folkman, S. (1984). Stress, appraisal, and coping, New York: Springer Publishing Company.

[57] Lewis, A. D., Huebner, E. S., Malone, P. S., \& Valois, R. F. (2011). Life satisfaction and student engagement in adolescents. Journal of Youth and Adolescence, 40(3), 249-262.

[58] Li, J.B., Delvecchio , E., Lis, A., Nie, Y.G. \& Di Riso, D. (2016). Positive coping as mediator between self-control and life satisfaction: Evidence from two Chinese samples. Personality and Individual Differences, 97, 130-133.

[59] Linley, P. A., Joseph, S., Harrington, S., \& Wood, A. M. (2006). Positive psychology: Past, present and (possible) future. Journal of Positive Psychology, 1(1), 3-16.

[60] Lyubomirsky, S., Sheldon, K. M., \& Schkade, D. (2005). Pursuing happiness: The architecture of sustainable change. Review of General Psychology, 9(2), 111-131.

[61] McCabe, K., Bray, M. A., Kehle, T. J., Theodore, L. A., \& Gelbar, N. W. (2011). Promoting happiness and life satisfaction in school children. Canadian Journal of School Psychology, 26(3), 177-192.

[62] McCrae, R.R. \& Costa, P.T. (1986). Personality, coping, and coping effectiveness in an adult sample, Journal of Personality, $54(2), 385-405$.

[63] McDonald, M. \& O'Callaghan, J. (2008). Positive psychology: A foucauldian critique. The Humanistic Psychologist, 36(2), 127-142.

[64] Meyers, M. C., Woerkom, M., \& Bakker, A. B. (2013). The added value of the positive: A literature review of positive psychology interventions in 93 organizations. European Journal of Work and Organizational Psychology, 22(5), 618-632.

[65] Mills, M. J., Fleck, C. R., \& Kozikowski, A. (2013). Positive psychology at work: A conceptual review, state-of practice assessment, and a look ahead. The Journal of Positive Psychology: Dedicated to Furthering Research and Promoting Good Practice, 8(2), 153-164.

[66] Natvig, G.K., Albrektsen, G., \& Qvarnstrøm, U. (2003). Associations between psychosocial factors and happiness among school adolescents. International Journal of Nursing Practice, 9, 166-175.
[67] Noddings, N. (2006). Eğitim ve mutluluk (Trans. Zuhal Bilgin). İstanbul: Kitap Yayıncılık.

[68] Nur-Şahin, G. (2011). Comparison of levels pertain to self-disclosure, subjective well-being and perceived social support of university students, Unpublished Master Thesis, Dokuz Eylül University Education Sciences Institute, , İzmir.

[69] Özdemir, Y., \& Koruklu, N. (2013). Parental attachment, school attachment and life satisfaction in early adolescence, Elementary Education Online, 12(3), 836 - 848.

[70] Pallant, J. (2011). SPSS Survival Manual A step by step guide to data analysis using SPSS (4th ed.). Australia: Allen \& Unwin.

[71] Penley, J. A., \& Tomaka, J. (2002). Associations among the big-five, emotional responses, and coping with acute stress. Personality and Individual Differences, 32, 1215-1228.

[72] Peterson, C., \& Seligman, M. E. P. (2004). Character strengths and virtues: A handbook and classification. New York: Oxford University Presss.

[73] Robertson, S. (1988). Social support: Implications for counselling. International Journal for the Advancement of Counselling, 11(4), 313-321.

[74] Sanders, M. G., \& Herting, J. R. (2000). Gender and the effects of school, family, and church support on the academic achievement of African-American urban adolescents. In M.G. Sanders (Ed.), Schooling students placed at risk: Research, policy, and practice in the education of poor and minority adolescents (pp. 141-161). Mahwah, NJ: Lawrence Erlbaum Associates.

[75] Sarriera, J. C., Bedin, L., Abs, D., Casas, F., \& Calza, T. (2015). Relationship between social support, life satisfaction and subjective well-being in Brazilian adolescents. Universitas Psychologica, 14(2), 459-474.

[76] Sayar, M. (2006). A longitudinal study of the relationship between perceived social support and psychological well-being of adolescent from low socioeconomic status. Unpublished Master Thesis. Boğaziçi University, Institute of Social Sciences. İstanbul.

[77] Seligman, M. E., \& Csikszentmihalyi, M. (2000). Positive psychology: An introduction. American Psychologist, 55(1), 5-14.

[78] Scheier, M. F., \& Carver, C. S. (1993). On the power of positive thinking: The benefits of being optimistic. Current Directions in Psychological Science, 2(1), 26-30.

[79] Yild1z, M. A. (2016). Multiple mediation of emotion regulation strategies in the relationship between loneliness and positivity in adolescents, Education and Science, 41(186), 217-231.

[80] Smith, E.L., Seltzer, M. M., Tager-Flusberg, H., Greenberg, J. S., \& Carter, A.S. (2008). A comparative analysis of well-being and coping among mothers of toddlers and mothers of adolescents with ASD. Journal of Autism and Developmental Disorders, 38(5), 876-889.

[81] Suldo, S. M. \& Huebner, E. S. (2006). Is extremely high life satisfaction during adolescence advantageous?. Social Indicators Research, 78, 179-203. 
[82] Suldo, S.M., Friedrich, A.A., White, T.N., Farmer, J., Minch, D., \& Michalowski, J. (2009). Teacher support and adolescents' subjective well-being: A mixed methods investigation. School Psychology Review, 38(1), 67-85.

[83] Suldo, S. M., \& Shaffer, E. J. (2008). Looking beyond psychopathology: The dual-factor model of mental health in youth. School Psychology Review, 37(1), 52-68.

[84] Şahin, N. H. (1994). Stres nedir? Ne değildir?. Stresle başa çıkma: Olumlu bir yaklaşım, Ankara: Türk Psikologlar Derneği Yayınları.

[85] Tabachnick, B. G., \& Fidell, L. S. (2013). Using multivariate statistics (6th ed.). New York: Allyn and Bacon.

[86] Teoman, D. D. (2015). Field study in positive psychology: Increasing resiliency and changing stress coping styles of employees with a gratitude intervention, Unpublished Doctoral Thesis, İstanbul University Social Sciences Institute, İstanbul.

[87] Terzi, Ş., \& Cihangir-Çankaya, Z. (2009). The predictive power of attachment styles on subjective well-being and coping with stress of university students, Turkish Psychological Counseling and Guidance Journal, 4(31), 1-11.

[88] Turner, G. (1999). Peer support and young people health. Journal of Adolescence, 22, 567-575.

[89] Tyler, P., \& Cushway, D. (1992). Stress, coping and mental well-being in hospital nurses. Stress and Health, 8(2), 91-98.
[90] Topal, M. (2011). Coping styles with stress of the university students and the relation between positive and negative emotion, Unpublished Master Thesis, Selçuk University Education Sciences Institute, Konya.

[91] Topbay, Y. (2016). Analysis of resilience levels of middle school students in terms of perceived social support and family functions, Unpublished Master Thesis, Beykent University Social Sciences Institute, İstanbul.

[92] Uyan, A. (2014). The relationship between perceived stress and social support in adolescence, Unpublished Master Thesis, İstanbul Arel University Social Sciences Institute, İstanbul.

[93] Wan, C. K., Jaccard, J., \& Ramey, S. L. (1996). The relationship between social support and life satisfaction as a function of family structure. Journal of Marriage and Family, $58(2), 502-513$.

[94] Wong, S. S., \& Lim, T. (2009). Hope versus optimism in Singaporean adolescents: Contributions to depression and life satisfaction. Personality and Individual Differences, $46,648-652$.

[95] Yarcheski, A., Mahon, N. E., \& Yarcheski, T. J. (2001). Social support and well-being in early adolescents: The role of mediating variables. Clinical Nursing Research, 10(2), 163-181.

[96] Yazgan-İnanç, B. Bilgin, M., \& Kılıç-Atıcı, M. (2007). Gelişim psikolojisi, çocuk ve ergen gelişimi, 3.Bask1, Ankara: Pegem Yayıncilık. 